Print ISSN: 2233-4165 / Online ISSN: 2233-5382

doi:http://dx.doi.org/10.13106/ijidb.2019.vol10.no10.67

\title{
A Study on the Global Start-ups/Employment Support Model Using ODA Projects*
}

\author{
$\mathrm{ODA}$ 프로젝트를 활용한 글로벌 창업/취업 지원 모델 \\ Moosup JUNG(정무섭)**, Jin-Sup JUNG(정진섭) $)^{* * *}$
}

Received: September 09, 2019. Revised: September 28, 2019. Accepted: October 05, 2019.

\begin{abstract}
Purpose - The purpose of this study was to explore the model that supports the recipient country by using the ODA (Official Development Assistance) project and at the same time fits the global start-up/employment support of donor country with CSV business model. Specifically, we wanted to examine the feasibility of the project based on the existing ODA projects.

Research design, data, and methodology - As the methodology, case studies and interview were conducted as well as literature studies. The case analysis is based on a press release of the entire KOICA's ODA project, which has been implemented for one year, based on 2017. After consideration, the actual results and future feasibility were analyzed. The interviews were conducted on senior Korean officials and Indian officials involved in Vietnam's ODA project.

Results - As a result, some of the project cases applied and analyzed according to the model of this study were judged to be highly potential. Based on the results of this analysis, as the model derived from this study pursues, the global business model is developed under the CSV (Creating Shared Value) strategy through ODA projects to support recipient countries and global start-up/employment support of donor country. The possibility of simultaneously pursuing this model based on CSV business model was also confirmed.

Conclusions - In the past, free aid agencies like KOICA focused solely on supporting recipient countries, but in terms of sustainability, they could discover the potential of supporting the global start-up/employment of the donor country using CSV business model in ODA project. In this study, we tried to find the theoretical background and potential possibilities in some ODA projects based on CSV business model. As a result of the analysis of KOICA ODA projects in 2017 and interviews, some ODA projects could be used to improve the economic development of the recipient country as well as the global start-up/employment of the donor country. Therefore, it is necessary for the ministries of the government to promote ODA projects to understand the framework that achieves these two objectives simultaneously and to promote ODA projects based on various strategic considerations.
\end{abstract}

Keywords: ODA (Official Development Assistance), Global Start-ups/Employment Support, Business Model (BM), Creating Shared Value (CSV), Korea International Cooperation Agency (KOICA)

JEL Classifications: F00, F21, 019.

* This paper was supported by the research fund of Dong-A University in 2019.

** First Author, Professor, The Department of International Trade, Dong-A University, Korea.

Tel: +82-10-6617-4122, Email: jungmoosup@hanmail.net

*** Corresponding Author, The School of International Business, Chungbuk National University, Korea.

Tel: +82-43-261-2340, Email: jsjung1@gmail.com

() Copyright: Korean Distribution Science Association (KODISA)
This is an Open Access article distributed under the terms of the Creative Commons Attribution Non-Commercial License (https://creativecommons.org/licenses/by-nc/4.0/) which permits unrestricte non-commercial use, distribution, and reproduction in any medium, provided the original work is properly cited.

\section{1. 서론: 연구의 배경}

공적개발원조(ODA, Official Development Assistance)의 주 요 목적은 수원국의 경제발전 및 복지향상에 있지만(Refaei \& Sameti, 2015), 세부 지원 동기는 다양하다(Leslie, Banks, Prinsen, Scheyvens, \& Stewart-Withers, 2018). 예를 들어, $\mathrm{ODA}$ 는 주로 긴급구호에 조력하기 위해, 수원국의 경제성장과 빈곤감소와 같은 개발 목표를 달성할 수 있도록, 공여국의 연 대감을 보여주기 위해, 공여국의 국익과 전략적 이익을 이루기 위해, 공여국의 상업적 이익을 증진하기 위해서 등 다양한 목 적으로 이뤄진다(Win \& Cho, 2018; Riddell, 2007, 2014; Park, 2016). 이러한 동기들을 좀 정리하면, 개발원조의 동기 
는 크게 “정치·외교적 동기, 경제적 동기, 인도주의 동기, 상호 의존 동기” 등으로 구분이 가능하다(Kim, 2002; Gai \& Jung, 2012).

한편, ODA 형태는 양자간과 다자간으로 구분되고, 양자간 ODA는 무상원조와 유상원조로 구분된다. 그리고 유상원조의 형태는 주로 차관, 주식취득(Acquisition of Equity) 형태임에 반하여, 무상원조는 프로젝트 및 프로그램 원조, 기술협력, 예 산지원, 식량원조, 긴급지원, 부채경감, NGO에 대한 지원, 공 공-민간 파트너십에 대한 기부금, 행정비용 등 다양하게 나타 난다(Graves, 2015; Gai \& Jung, 2012).

한국은 수원국에서 공여국으로 변신한 역동적 국가로서, 이 제 ODA의 전략도 변화가 필요하다. 특히, 그 양적인 측면과 질적인 측면에서 점차 그 역할의 확대가 긴요한 상황이다 (Perekunah \& Oziegbe, 2016; Graves, 2015; Baxter, 2016; Jung, 2010; Gai \& Jung, 2012; Benmamoun \& Lehnert, 2013). 예를 들어, 무상원조라 할지라도 단순히 무조건적인 원 조보다는 지속가능하고 상호 이해를 증진하는 방향으로 전략 적 변화가 나타나고 있다. 최근 대표적인 무상원조 기관인 $\mathrm{KOICA}$ 의 경우, ODA 자금을 이용하여 청년들 중심의 글로벌 창업이나 취업을 지원하는 모델의 구축 등 다양한 모델을 모 색하고 있다. 즉, ODA 프로젝트의 수행을 통해 수원국 성과를 높이는 동시에 공여국 관점에서 글로벌 창업 또는 취업을 통 한 일자리 창출의 가능성도 탐색하는 것이다.

그런데 무상원조기관인 KOICA가 이러한 목적을 가지는 것 이 타당하며, 현실적으로 가능한가라는 문제가 남아있다. 보다 구체적으로는 기본적 실행 모델로서 ODA사업자금을 활용해 (1) 공유가치 창출(CSV, Creating Shared Value)(Porter \& Kramer, 2011)이나 BOP(Bottom of the Pyramid) 전략 (Prahalad, 2004) 기반의 비지니스 모델(BM, Business Model) 개발과, (2) 이러한 구체적 비즈니스 모델의 실행역량을 가진 창업자에 대한 글로벌 창업 지원 또는 취업 지원, 그리고 (3) 이를 통한 수원국 지원성과의 달성이라는 측면을 동시에 달성 이 가능한지에 대한 이슈이다(Jung \& Lee, 2012).

이후 본 논문의 진행은 다음과 같다. 먼저 제2장에서는 공 유가치창출(CSV)과 ODA, 고용창출 관련 연구에 대한 고찰과 더불어 2017년 수행된 KOICA 사업을 조사하였다. 이러한 선 행조사를 통해 공유가치창출(CSV)의 개념과 공여국의 고용창 출이 어떻게 ODA와 연계될 수 있는지 고찰하고자 하는 것이다. 제3장에서는 먼저 ODA와 글로벌 창업 또는 취업 지원 모델이 공존할 수 있는지에 대해 본 연구 모델을 활용하여 분석하여 보고, 이어 관련 공무원 및 관계자를 중심으로 인터뷰 내용을 정리하였다. 그리고 이러한 내용을 토대로 한국적 ODA 전략을 모색해보고자 했다. 끝으로 제4장의 결론 부문에서는 ODA를 활용한 글로벌 창업 또는 취업 지원 모델의 실현가능성을 평 가하고, $\mathrm{UN}$ 의 지속가능발전종합목표(SDGs, Sustainable Development Goals)의 기반하에서 이러한 모델을 조명하고자 했으며, 본 연구의 의의와 한계점을 논의하고자 한다.

\section{2. 기존 문헌 및 2017년 KOICA 사업 조사}

\section{1. 공유가치창출과 $\mathrm{ODA}$}

Porter and Kramer(2011)는 기업이 사회적 책임(CSR,
Corporate Social Responsibility) 뿐만 아니라 사회적 가치와 기업의 경제적 가치를 동시에 충족시키는 공유가치창출(CSV, Creating Shared Value) 전략을 추구해야 한다고 주장했다. <Table 1>을 통해 사회적 책임(CSR)과 공유가치창출(CSV)이 라는 두 가지 상생의 내용을 비교하면 다음과 같다.

Table 1: Comparison of Win-win Content: Social Responsibility and Creating Shared Value

\begin{tabular}{|c|c|c|}
\hline Division & $\begin{array}{c}\text { Corporate Social } \\
\text { Responsibility (CSR) }\end{array}$ & $\begin{array}{l}\text { Creating Shared Value } \\
\text { (CSV) }\end{array}$ \\
\hline $\begin{array}{l}\text { Pursuit of } \\
\text { value }\end{array}$ & Good deed & $\begin{array}{c}\text { Economy that exceeds input } \\
\text { costs, Sharing of social } \\
\text { revenue }\end{array}$ \\
\hline Example & $\begin{array}{l}\text { Civil responsibility, } \\
\text { charity, environmental } \\
\text { protection, etc. }\end{array}$ & $\begin{array}{c}\text { Joint ventures and } \\
\text { Community value creation }\end{array}$ \\
\hline $\begin{array}{l}\text { Pursuit of } \\
\text { profitability }\end{array}$ & $\begin{array}{l}\text { Apart from a profit } \\
\text { maximization strategy }\end{array}$ & $\begin{array}{c}\text { Essential element for } \\
\begin{array}{c}\text { competition and maximizing } \\
\text { revenue }\end{array}\end{array}$ \\
\hline $\begin{array}{l}\text { Agenda } \\
\text { setting }\end{array}$ & $\begin{array}{l}\text { Agenda setting based on } \\
\text { external needs or } \\
\text { reader's decision }\end{array}$ & $\begin{array}{l}\text { Agenda setting based on } \\
\text { firm's internal needs }\end{array}$ \\
\hline $\begin{array}{r}\text { Relevance } \\
\text { of budget }\end{array}$ & $\begin{array}{c}\text { Activities are limited } \\
\text { by the size of CSR } \\
\text { budget }\end{array}$ & $\begin{array}{l}\text { Based on CSV, } \\
\text { entire budget is reorganized }\end{array}$ \\
\hline
\end{tabular}

Source: Porter \& Kramer (2011)

또한 이러한 CSV 전략은, 기업이 계층피라미드의 아래쪽에 자리 잡고 있는 사람들을 대상으로 한 비즈니스 활동을 통해 신흥국이 가난을 극복할 수 있다는 Prahalad(2004)의 BOP (Bottom of Pyramid) 전략과 ODA 사업의 수행측면에서 다소 일맥상통하는 측면이 있다. 즉, ODA의 기본 정신에 따라 수원 국에 도움이 되지만, 동시에 공여국에도 도움이 될 수 있는 비 즈니스 모델을 추구한다는 것이다.

이러한 개념을 $\mathrm{ODA}$ 관점에서, 이를 좀 더 체계화하여 Jung, Lee, and Yoon (2014)은 <Figure 1>와 같은 Smart ODA 모델을 제시하였다.

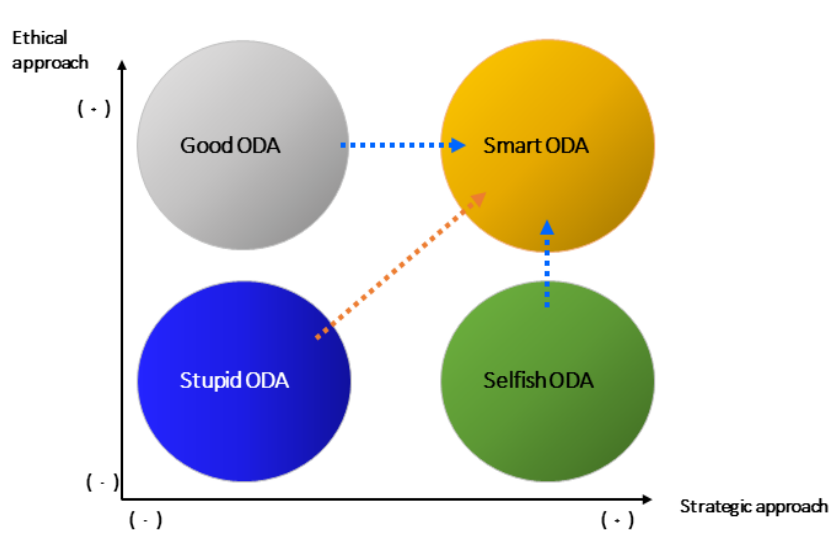

Source: Jung, Lee, and Yun (2014).

Figure 1: The Concept of Smart ODA 
이를 설명하면 다음과 같다. 기본적으로 윤리적 측면(즉, 사 회적 측면)과 전략적 측면(즉, 경제적 측면)이라는 두 축을 가 지고 ODA의 형태를 설명하는 것이다. 이기적인 ODA(Selfish $\mathrm{ODA})$ 는 공여자의 힘(Power)을 활용하여, 수원국의 이익보다는 자신의 이익을 도모하는 것이다. 예를 들면, 원조를 빌미로 건 설플랜트를 수주하거나 제품을 판매하는 행위 등이다. 착한 $\mathrm{ODA}(\mathrm{Good} \mathrm{ODA})$ 는 오로지 공여국의 인류공영 또는 사회적 책임을 중시하고 식량지급과 같은 자선 형태의 무상원조에 집 중하는 것으로서, 대가 없이 공여국의 지원(금전, 자원 등)을 수원국에 제공한다. 문제는 이러한 원조가 그 이후에도 지속되 기 어렵고 수원국의 원조효과가 일시적이어서, 중장기적으로 수원국과 공여국 모두의 경제발전에 도움이 되지 못할 수 있 다는 것이다. 반면, 어리석은 ODA(Stupid ODA)는 공여국이 원조를 하지 않고, 따라서 수원국도 그 혜택을 받지 못하는 경 우이다. 이 모델의 핵심은 결국 윤리적 측면과 전략적 측면을 모두 고려하여, 수원국과 공여국이 모두 중장기적으로 Win-win 할 수 있는 스마트 ODA 방향을 선택해야 한다는 것이다(Jung et al., 2014; Jin, 2018).

한편, Ministry of Economy and Finance(2014), Jung(2012), Jung and Khoe(2013)에서는 신흥국 진출과 관련이 깊은 CSV 기반의 상생-복합형 진출 전략과 국가차원의 신흥국 경제협력 전략을 종합적으로 밝히고 있으며, 기본적인 ODA 사업의 전 략적 방향 측면에서 참고가 될 수 있을 것으로 판단된다
<Figure 2>. 한국의 저개발국 지원에 있어서, 지속가능한 성과 를 극대화하기 위해서는 민간의 비즈니스 동기에 기반을 둔 공유가치창출 전략이 매우 중요하다. 이러한 관점에서 볼 때, 수원국(recipient country)에 고용창출, 소비자 혜택 증가 등 실 질적인 도움을 주기 위해서는 공여국(donor country)인 한국에 게도 청년 창업의 성공과 일자리 창출 등의 효과가 있어야, 중 장기적으로 양자 간의 지속적인 사업을 통한 발전이 가능하며, 따라서 ODA 자금은 이와 같은 지속가능한 양국 간 가치공유 를 기반으로 글로벌 사업의 마중물 역할을 수행하는 것이 중 요하다. 따라서 수원국 지원에서는 진출국에서 사회적 책임을 수행하는 CSR 활동뿐 아니라(Kim \& Kim, 2019), 사업 자체를 활용해 공유가치를 창출하는 CSV 측면도 함께 추진하는 것이 필요한 시대가 왔다(Ghasemi, Nazemi, \& Hajirahimian, 2014).

예를 들어, 기업 이미지 향상을 위한 사회공헌 활동이나 기 부뿐만 아니라 생산과정과 제품개발에서 사회적 가치를 탄생 시킬 수 있는 방법의 모색이 필요하다. 예를 들어, 공유가치창 출을 달성하기 위해 신흥국 로컬 공급처의 수준과 생산성 개 선을 지원하는 사업이나 신흥국 노동력의 질적 개선을 위한 투자 등이 필요할 수 있다. 특히 신흥국 진출의 경우, 갈등 및 상생이 동시에 발생할 수 있으므로, 정부 차원의 ODA 전략하 에서 상생의 선순환구조를 만드는 것이 중요하며, 이는 민간 진출과의 시너지 창출에서도 매우 필요하다. 외국기업의 신흥 국 진출의 경우, 기술과 자본 등 이전으로 경제발전에 기여할

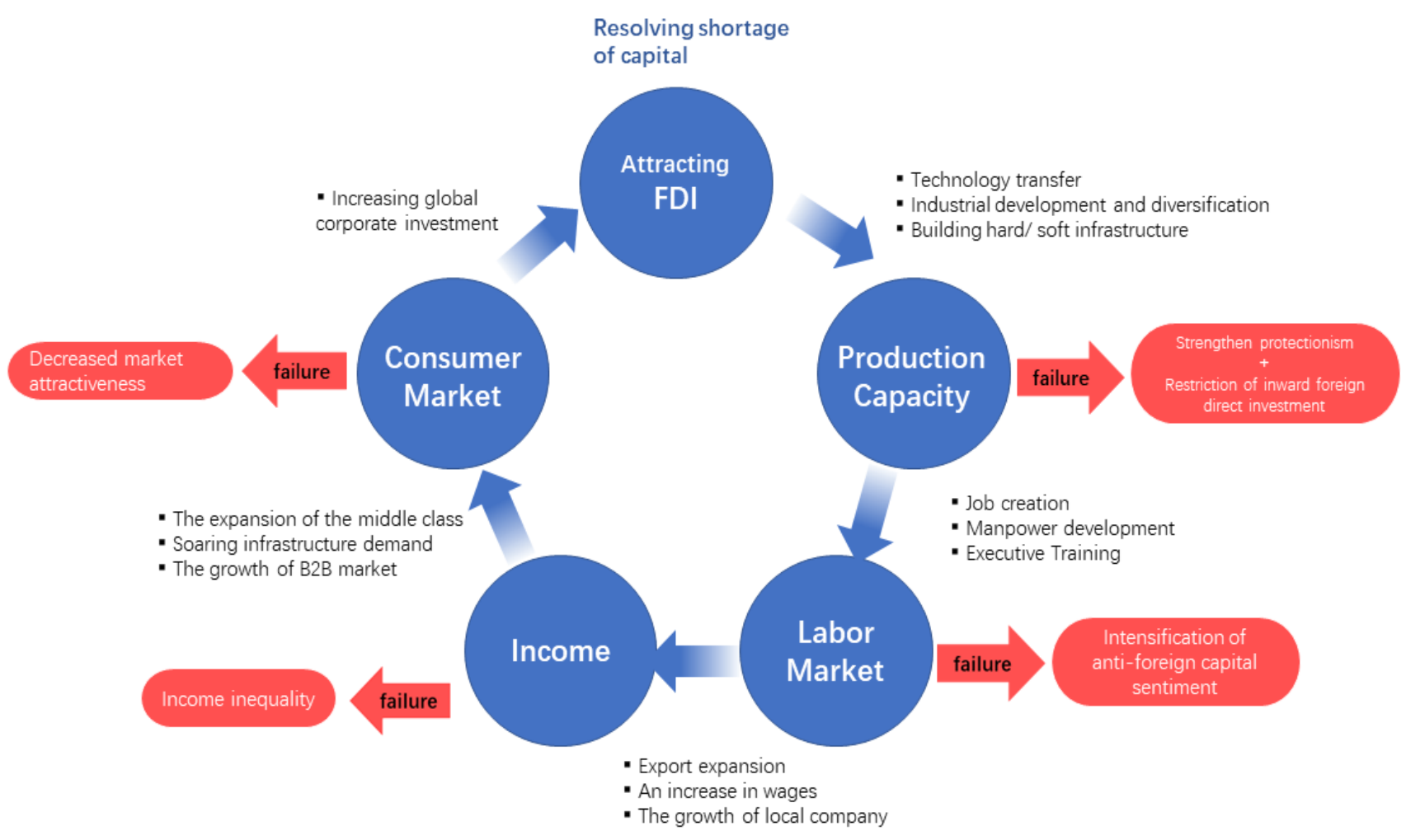

Source: Jung et al. (2012).

Figure 2: Win-win Partnership Structure Between Global Company and Economic Growth of Target Country 
수도 있지만 자국 산업 발전의 저해 등 갈등요인도 존재하며 결국 ODA 자금은 신흥국 경제성장의 중요한 도구로서 성장의 선순환 도구로 만들어야 한다. 기본적으로 Park, Kim, and Lee (2014)와 Kim(2016) 등과 같이 ODA 관련 기존연구가 다 수 존재하고 있으나, 본 연구와 같이 공여국의 고용창출과 관 련된 연구는 드문 상황이며, 따라서 본 연구는 이러한 부문에 초점을 두고 진행하고자 한다.

\section{2. 고용창출 관련 연구}

Korea Labor Institute(2016)에 따르면, ODA 사업을 아래와 같이 유형별로 직접고용, 간접고용, 해외취업의 형태를 가질 수 있으나, 기술적 통계로 도출할 수 있는 정책적 시사점은 크 지 않은 상황이다. 이를 항목별로 구분하여 약술하면 <Table 2>와 같다.

예산 지원과 채무 구제를 제외하고 모든 원조 유형에서 직 접고용과 간접고용이 혼재되어 나타난다. 그러나 주된 경비지 출이 이루어지는 장소에 따라 해외에서 취업이 이루어지면 해 외취업 형태가 된다. 또한, NGO.PPP 지원이나 프로그램 원 조, 그리고 프로젝트 원조의 경우, 경비집행이 국내와 국외에 서 이루어지기 때문에 해외취업과 국내의 직간접 고용의 형태 로 나타난다. 기금지원이나 국제기구 프로그램의 경우에는 해 외취업이 발생하게 된다. 한국산 기자재의 해외조달의 경우에
는, 국내의 간접고용이 발생한다. 행정비용의 경우, 직접고용 을 창출하지만, 개도국 유학생 및 연수생 지원, 기술원조, 난 민지원, 개발인식 확산은 국내의 직접 및 간접 고용을 발생시 키며 기술 원조의 경우에도 자금이 해외로 이전되어 집행될 경우 해외취업이 유발된다.

한국은 ILO 아태지역의 핵심 공여국으로서, 협력 사업을 통 해 ILO의 핵심 목표인 국제노동기준 실현과 양질의 일자리 창 출을 위한 개도국의 역량을 강화하기 위한 노력을 수행하고 있는 상황이다.「한-ILO 협력사업」은 한국 기업이 다수 진출해 있는 캄보디아, 미얀마, 라오스, 베트남(CLMV 국가)의 숙련기 술인력 양성과 산업안전보건증진, 산재예방을 위한 활동을 주 로 지원하고 있다(Lee, 2017). 또한 KOTRA(2011)에 따르면, 미국의 ODA가 공적원조 수원국과 다국적 개발기구를 지원하 는데, $\mathrm{OECD}$ 내 개발원조원회(DAC)의 국가원조 지원 리스트 국가들에 지원되는 원조와 월드뱅크의 국제개발기구(IDA) 등 과 같은 다국적 기구에 대한 지원이 구분되어 있음을 보여준 다. 또한 그러한 성공·실패 사례도 분석하고 있다. 한편, "Emergency Communications Development Project”라는 사업 은 아프가니스탄의 통신 서비스 개선 프로젝트인데, 이를 통해 아프간 내 통신 산업 관련 고용과 수익이 기하급수적으로 증 가했다. 아프간 내 통신 산업의 경우, 직간접적으로 6 만 명의 고용 창출이외에, 정부수입 7,500 만 달러를 기여하고 있다.

Table 2: "Governmental Self-evaluation" of ODA Employment Effects: Comparison of Existing and Revised Aggregation Results

\begin{tabular}{|c|c|c|c|c|c|c|}
\hline \multirow[b]{2}{*}{ Project } & \multirow[b]{2}{*}{ Total effect } & \multicolumn{3}{|c|}{ Category } & \multirow{2}{*}{$\begin{array}{c}\text { Total budget } \\
(100 \text { million won) }\end{array}$} & \multirow{2}{*}{$\begin{array}{l}\text { Billion won } \\
\text { Employment } \\
\text { Effect }\end{array}$} \\
\hline & & Direct effect & Indirect effect & $\begin{array}{l}\text { Overseas } \\
\text { Employment }\end{array}$ & & \\
\hline $\begin{array}{l}\text { International Agricultural } \\
\text { Cooperation }\end{array}$ & & & & & & \\
\hline A. Traditional formula & 155.0 & 0.0 & 154.0 & 1.0 & 170.2 & 9.1 \\
\hline $\begin{array}{l}\text { B. Modified formula } \\
\text { International Organizatior } \\
\text { Entry Support }\end{array}$ & 41.9 & 0.0 & 26.6 & 15.3 & 170.2 & 2.5 \\
\hline A. Traditional formula & 11.4 & 11.0 & 0.4 & 0.0 & 31.0 & 3.7 \\
\hline $\begin{array}{l}\text { B. Modified formula } \\
\text { United Nations Volunteer }\end{array}$ & 21.4 & 0.9 & 0.5 & 20.0 & 31.0 & 6.9 \\
\hline A. Traditional formula & 67.7 & 67.7 & 0.0 & 0.0 & 34.1 & 19.9 \\
\hline $\begin{array}{l}\text { B. Modified formula } \\
\text { Strengthening Public } \\
\text { Diplomacy Capabilities }\end{array}$ & 62.0 & 0.0 & 0.0 & 62.0 & 34.1 & 18.2 \\
\hline A. Traditional formulal & 97.8 & 23.5 & 74.3 & 0.0 & 108.0 & 9.1 \\
\hline $\begin{array}{l}\text { B. Modified formula } \\
\text { Overseas Korean Found } \\
\text { appearance }\end{array}$ & 97.1 & 23.5 & 33.6 & 40.0 & 160.0 & 6.1 \\
\hline A. Traditional formula & 748.8 & 112.3 & 636.5 & 0.0 & 498.5 & 15.0 \\
\hline B. Modified formula & 572.2 & 112.3 & 384.9 & 75.0 & 498.5 & 11.5 \\
\hline
\end{tabular}

Source: Korea Labor Institute (2016), p.52. 
Lee(2016)의 경우, UNIDO의 기술혁신 프로그램 사례로서 이라크의 기술적 지원 프로그램을 제시하였다. 그는 상대적으 로 안정된 인플레이션과 지속적인 경제성장이 양(+)의 재정수 지 균형을 이루고 있었지만, 그럼에도 불구하고, 이라크의 전 반적 경제는 부의 창출 및 고용창출에 아직 적절한 자극을 주 지 못했다고 지적하면서, 주로 현지국의 고용창출효과에 대한 연구에 집중하였다. 청년 창업과 관련된 기존연구는 다수 존재 하지만(Min, Huh, \& Han, 2018), 글로벌 비즈니스에서의 창업 (start-up)이나 ODA를 활용한 글로벌 창업 연구는 아직 희소한 상황이다. 본 연구에서는 이와 같이 ODA를 활용한 창업 (start-up) 또는 취업 지원과 관련된 연구로서는 기존연구와 차 별화를 시키고자 한다.

또한 Lee $(2013,2014)$ 등에서 언급하고 있는 바와 같이 대 기업 등을 통한 일자리 창출은 한계에 도달해 창업이 유력한 대안으로 제시하고 있으며, 기업가정신 활성화를 통한 창업을
통해 국가차원의 새로운 성장 동력 확보가 절실한 상황이다. 한편, 세계기업가정신발전기구(GEDI)가 발표한 2017 세계 기 업가정신 지수(GEI, Global Entrepreneurship Index)에 따르면, 한국의 기업가정신은 2015년에 대비 1단계 상승하여 20162017년 27위이나, OECD 34개국 중에서는 중하위권인 23위로 작년보다 1단계 하락하였다(Park, 2017).

\subsection{7 년 코이카 사업의 분석}

다음에서는 구체적으로 2017년도를 기준으로 1년 동안 실 행된 고용부와 코이카의 ODA 사업 전체를 기관의 보도 자료 를 통해 조사하였다. 그리고, 이러한 사업들 중 본 연구에서 도출된 모델을 적용해 볼 수 있는 사업들을 대상으로 실제 나 타난 결과와 향후 모델적용의 가능성을 살펴보았다<Table 3>.

Table 3: KOICA Press Release in 2017 \& Evaluation of Applicability in Start-up/ Employment Support Model by ODA Utilization

\begin{tabular}{|c|c|c|c|}
\hline No. & Date & Title of press & $\begin{array}{c}\text { Evaluation of model } \\
\text { applicability }\end{array}$ \\
\hline 1 & $2017-01-20$ & KOICA establishes Forest Management Research Center in Solomon Islands, South Pacific. & Unapplied \\
\hline 2 & $2017-02-02$ & KOICA carries out volunteer service for Cambodian Korean students & Applied \\
\hline 3 & 2017-02-17 & $\begin{array}{l}\text { KOICA holds ceremony for rebuilding fishing port in Typhoon Damaged by lloilo in Northern } \\
\text { Philippines. }\end{array}$ & Unapplied \\
\hline 4 & 2017-04-21 & $\begin{array}{l}\text { KOICA hosts workshop to complete flood forecast and warning system in Chita Lum River } \\
\text { Basin, Indonesia. }\end{array}$ & Unapplied \\
\hline 5 & 2017-04-26 & $\begin{array}{l}\text { KOICA signed an agenda for consultation on climate change response projects ('17 '20 / \$8 } \\
\text { million) by increasing water resilience in eastern El Salvador. }\end{array}$ & Unapplied \\
\hline 6 & 2017-04-27 & $\begin{array}{l}\text { KOICA takes the first step in capacity building for Halla Vocational Development Institute, } \\
\text { Laos. }\end{array}$ & Unapplied \\
\hline 7 & $2017-05-10$ & KOICA launched initiation briefing session of "the transport sector DEEP Project in Vietnam" & Unapplied \\
\hline 8 & $2017-05-18$ & KOICA-Korea Railroad Research Institute full-fledged "Vietnam railroad technology support". & Unapplied \\
\hline 9 & $2017-06-15$ & KOICA establishes general hospital in Oruro City, Bolivia. & Applied \\
\hline 10 & $2017-06-15$ & KOICA-Kia Motors turns green light on Automotive Maintenance in Ethiopia. & Applied \\
\hline 11 & $2017-06-23$ & KOICA carries out R\&D infrastructure construction project for regional development in Nepal. & Unapplied \\
\hline 12 & 2017-06-26 & KOICA and CJ achieved rural development together in Vietnam & Applied \\
\hline 13 & $2017-06-29$ & KOICA in Rwanda Office holds groundbreaking ceremony for ICT Innovation Center & Unapplied \\
\hline 14 & 2017-07-07 & $\begin{array}{l}\text { KOICA supports } 36 \text { kinds of statutory metering materials to improve Bolivia's national } \\
\text { standard system. }\end{array}$ & Unapplied \\
\hline 15 & $2017-07-13$ & KOICA supports Philippine police investigation. & Unapplied \\
\hline 16 & $2017-07-17$ & Uganda, "Will try rice processing miracle in rice processing?" & Applied \\
\hline 17 & 2017-07-21 & KOICA transfers road maintenance management technology in Mozambique, Africa & Unapplied \\
\hline 18 & $2017-08-01$ & KOICA carries out "cinema heaven" in Peru & Unapplied \\
\hline 19 & $2017-08-02$ & KOICA establishes "Cambodia-Korea Rural Development Institute" in Cambodia & Unapplied \\
\hline 20 & 2017-08-17 & $\begin{array}{l}\text { KOICA conducts 'invitation training' to improve the environment of elementary schools in } \\
\text { Kenya }\end{array}$ & Unapplied \\
\hline 21 & $2017-08-21$ & KOICA hosts 11th Seoul ODA International Conference & Unapplied \\
\hline 22 & $2017-08-28$ & KOICA contributes to Senegal rice self-sufficiency using system of recipient country & Applied \\
\hline 23 & $2017-09-20$ & KOICA establishes first deaf special school in Jordan. & Unapplied \\
\hline 24 & $2017-09-29$ & A dream of service that has never been achieved! & Applied \\
\hline 25 & $2017-09-29$ & KOICA opens Integrated Project Management Partner Information System & Unapplied \\
\hline 26 & $2017-10-17$ & KOICA hosts the completion ceremony of the "Lao Cai Cai Happiness Program" in Vietnam & Unapplied \\
\hline 27 & $2017-10-25$ & $\begin{array}{l}\text { The Dominican Republic secures new growth engines through industry-academic cooperation } \\
\text { R\&D. }\end{array}$ & Unapplied \\
\hline 28 & $2017-10-27$ & KOICA carries out civil society organization capacity building education in Mongolia. & Unapplied \\
\hline 29 & $2017-11-07$ & KOICA works on restoration of Angkor Wat Ruins in Cambodia & Unapplied \\
\hline 30 & 2017-11-16 & KOICA nurtures rural village leaders by establishing Myanmar Rural Development Institute & Applied \\
\hline
\end{tabular}


총 30 개의 사업이 검색되었으며, 그 중 미적용이 22 개 사업 $(=22 / 30=73.33 \%)$ 이며, 적용 가능한 사업이 8 개 $(=8 / 30=26.67 \%)$ 로 분석되었다. 기본적으로 $\mathrm{KOICA}$ 는 기관의 특성상 무상원조 를 수행하기 때문에 미적용 사례가 다수를 차지한 것은 당연 할지도 모른다. 그러나 비교적 작은 수의 사업이지만, 이제는 글로벌 창업 지원이나 일자리 창출이 가능한 사업도 가능하다 는 결과를 보여주고 있다. 나아가 이러한 방향으로 거시적 전 략을 강구한다면, 향후 그 비율이 증가될 가능성도 충분히 내 재하고 있다.

\section{3. 글로벌 창업/취업 지원 모델, 인터뷰 및 한국적 ODA 전략 모색}

전술하였듯 공유가치창출(CSV)과 ODA 관계 및 고용창출 관련 연구에 대한 고찰과 더불어 2017년 수행된 KOICA 사업 도 살펴보았다. 이러한 선행조사를 통해 공유가치창출(CSV)의 개념과 같이 수원국의 지원이라는 ODA의 본연의 역할과 동시 에 공여국의 고용창출도 ODA와 연계될 수 있는 방법을 고찰 하고자 하는 것이 본 연구의 핵심 목적이다. 다음에서는 $<$ Figure $3>$ 의 제시된 모델을 기반으로 기존의 ODA 사업에 대 해 고찰하고자 한다.

즉, 앞에서 도출된 ODA를 활용한 글로벌 창업/취업 지원 모델을 기반으로 구체적인 사례를 분석하여 해당 모델의 관점 에서 발전방향을 고찰함으로써, 향후 정책방향과 시사점을 제 시하고자 한다. 추후 이러한 사례의 고찰을 통해 우선 고용노 동부에서 이와 같이 ODA 자금을 활용하여 기존 수행하고 있 는 사업 중 모델 적용을 통해 분석이 가능한 정책을 조사해 보고, 이외에 외교부, 산업통상자원부 등 다른 부처에서 수행 하고 있는 ODA 사업에서 공여국 고용창출의 측면(글로벌 창 업(취업 지원)을 고려하여, 부처 간 협업이 가능한 사업도 이 와 같은 모델 적용을 시도할 수 있을 것으로 판단된다.

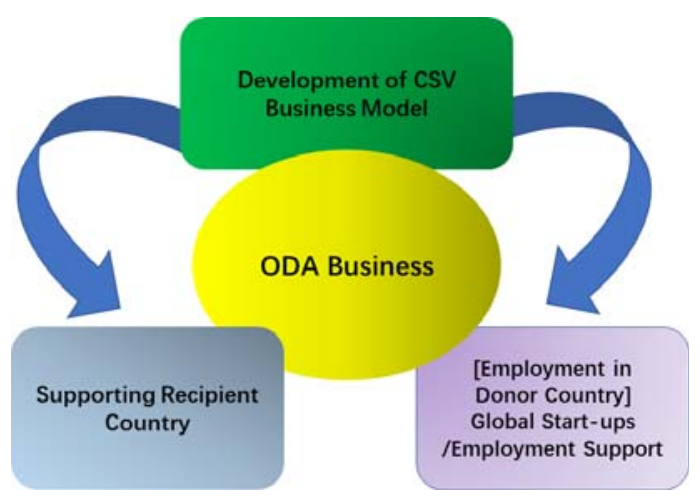

Figure 3: New Perspective of ODA Business: Relationship Between Development of CSV Business Model, Recipient Country Support and Global Start-up/Employment Support of Donor Country

\section{1. 글로벌 창업/취업 지원 모델과 그 적용사례}

\subsection{1. 코이카 해외봉사단 파견 사업 및 연계 발전방안}

$<$ Table 4>에서와 같이 기존에 ODA를 활용하는 KOICA 해 외봉사단과 관련하여 ODA를 활용한 글로벌 창업/취업 지원 모델로 분석한 결과, 현지 비즈니스 모델 및 글로벌 창업/취업 지원과의 연계를 통해 그 발전가능성이 있는 것으로 분석되었 다. 즉, 고용노동부의 ODA 자금을 활용해 코이카 등 관련부서 와 협력하는 청년봉사단 활동 중 희망자를 통해 직·간접적인 참여 등을 활용해서 현지 비니니스 모델 개발을 지원하고, 활 동 종료 전후를 기점으로 실제 창업 또는 기존 기업과 연계한 고용창출로 이어질 수 있는 정책 추진도 가능할 것으로 판단 된다(KOICA, 2017a).

Table 4: Analysis Using KOICA's Model for Dispatching Overseas Volunteers

\begin{tabular}{|c|c|}
\hline Items & Summary of Content \\
\hline Business overview & $\begin{array}{l}\text { The Overseas Volunteer Dispatch Project provides Korea's young workers with opportunities to participate in } \\
\text { training and technology transfer in the economic and social development of developing countries by sending } \\
\text { volunteers to participate in education and vocational education, agriculture, fisheries, health, sanitation and rural } \\
\text { development. } \\
\text { By transferring development experience of Korea to improve the quality of life of local residents in developing } \\
\text { countries (technology transfer, higher income levels and improved living environment); Promote friendly relations } \\
\text { and cooperation between developing countries and mutual understanding between the two countries (exchange } \\
\text { history, culture and traditions of Korea and other countries); in order to return domestic experiences of overseas } \\
\text { volunteering activities (to form a public consensus on overseas volunteering by returning domestic community of } \\
\text { volunteering experiences). } \\
\text { Types of participation are as follows: (1) Field participation (active in the field with local residents in agricultural } \\
\text { development, water conservancy projects, regional development, youth guidance, health care, farming guidance), } \\
\text { (2) Educational guidance (through the teaching and guidance of universities, vocational schools, vocational } \\
\text { education institutions and other educational institutions to achieve technology and knowledge transfer for local } \\
\text { human resource development), (3) Research office type (transfer Korean development experience and technology } \\
\text { to foreign local experts in offices or laboratories with professional skills, and provide advice), (4) Work-linking } \\
\text { types (using local people, resources, funds, etc. to participate in local projects or to develop small projects by } \\
\text { volunteers) }\end{array}$ \\
\hline $\begin{array}{l}\text { [1] Supporting } \\
\text { recipient country }\end{array}$ & $\begin{array}{l}\text { Most of projects are only aim to support recipient countries } \\
\text { However, there are some limitations to promoting the effectiveness of development in recipient countries through } \\
\text { sustainable support rather than one-time support. }\end{array}$ \\
\hline
\end{tabular}


[2] Development of CSV business model

[3] Global start-ups lemployment Support
Improvement directions: Try to develop a private business model that builds creating shared value (CSV). This business model can be best done by a group of young overseas volunteers who have worked for a long time in the local area and are familiar with local circumstances. however there are no policies or incentives to motivate these young volunteers to develop business models, so it is difficult to occur in reality.

Improvement directions: If there are various attempts, such as incubation and accelerating support, which can lead to actual investment, start-up, and job creation, the business model developed based on government ODA funding after the volunteer group's overseas activities or period ends, there are also possibilities of new global employment or start-ups.

Table 5: Dispatch Status by KOICA Volunteer Corps by Year/Country (Including Youth Middle/NGO, Except Advisory Group)

\begin{tabular}{|c|c|c|c|c|c|c|c|c|c|c|}
\hline Division & Total & $\mathbf{2 0 0 8}$ & $\mathbf{2 0 0 9}$ & $\mathbf{2 0 1 0}$ & $\mathbf{2 0 1 1}$ & $\mathbf{2 0 1 2}$ & $\mathbf{2 0 1 3}$ & $\mathbf{2 0 1 4}$ & $\mathbf{2 0 1 5}$ & $\mathbf{2 0 1 6}$ \\
\hline Sum & 6,815 & 822 & 851 & $\mathbf{7 9 7}$ & 783 & 813 & 842 & 985 & 922 & 911 \\
\hline Mongolia & 463 & 40 & 44 & 44 & 52 & 31 & 37 & 116 & 99 & 67 \\
\hline Cambodia & 412 & 31 & 48 & 46 & 49 & 37 & 47 & 60 & 94 & 68 \\
\hline Vietnam & 339 & 39 & 49 & 33 & 40 & 25 & 41 & 67 & 45 & 56 \\
\hline Sri Lanka & 328 & 28 & 38 & 44 & 27 & 39 & 23 & 67 & 62 & 93 \\
\hline Ethiopia & 290 & 21 & 21 & 37 & 35 & 45 & 53 & 44 & 34 & 32 \\
\hline Indonesia & 273 & 43 & 45 & 52 & 30 & 33 & 22 & 18 & 30 & 24 \\
\hline Bangladesh & 225 & 27 & 31 & 29 & 41 & 23 & 26 & 45 & 3 & 2 \\
\hline Nepal & 212 & 19 & 29 & 36 & 34 & 18 & 37 & 22 & 17 & 18 \\
\hline Etc. & 4,273 & 574 & 546 & 476 & 475 & 562 & 556 & 546 & 538 & 551 \\
\hline
\end{tabular}

Source: World Job Plus, KOICA Volunteers (Including Youth Middle/NGOs, Except Advisory Group) by Year/Country

Table 6: Business Support Plan Linking Private Company's Investment and ODA Funds

\begin{tabular}{|c|c|}
\hline Items & Summary of Content \\
\hline Business overview & $\begin{array}{l}\text { CJ has established Saemaul farmers' organizations, village infrastructure, agricultural machinery banks, red pepper } \\
\text { crop farming, joint workshops and processing plants, and especially committed to improving the village } \\
\text { environment and building infrastructure in Vietnam. In order to increase the income of Vietnamese farmers and } \\
\text { boost their self-sufficiency, CJ Group, together with KOICA, built a pepper powder processing plant in Vietnam. } \\
\text { Kia Motors trains skilled workers by working with Kia's expertise and expertise to contribute to creating a stable } \\
\text { and sustainable source of income in Ethiopia. In particular, the company plans to adopt an inclusive business } \\
\text { model to improve service levels in the local automotive maintenance sector. It also operating an inclusive } \\
\text { business plan locally, and through strategic partnerships with local companies, to contribute to the sustainable } \\
\text { growth of the economies and resident's quality of life in developing countries. } \\
\text { Lotte, which participated in KOICA's Vietnam distribution industry support project, to solving social problems in } \\
\text { developing countries and reinforcing corporate core competitiveness by utilizing private resources and strategies. }\end{array}$ \\
\hline $\begin{array}{l}\text { [1] Supporting } \\
\text { recipient } \\
\text { country }\end{array}$ & $\begin{array}{l}\text { the private sector participates in the existing KOICA project, basically there are some support effects of } \\
\text { cipient countries. } \\
\text { tere are additional investment possibilities depending on the needs of the private sector, and sustainability also } \\
\text { ists because it can be used as an intermediary for official development assistance (ODA) projects. }\end{array}$ \\
\hline $\begin{array}{l}\text { [2] Develop } \\
\text { CSV bi } \\
\text { model }\end{array}$ & $\begin{array}{l}\text { At present, support for BM development, which is a company-centered business, is weak. } \\
\text { In addition to official development assistance in the form of one-sided donations, it is necessary to support a } \\
\text { company-oriented and CSV-based global business model that will help increase the income of recipient countries, } \\
\text { improve consumer value and industrial development, while enabling investment companies to achieve } \\
\text { commercialization. }\end{array}$ \\
\hline $\begin{array}{l}\text { [3] Global s } \\
\text { lemployn } \\
\text { Support }\end{array}$ & $\begin{array}{l}\text { The business model developed in connection with the companies may create employment opportunities within the } \\
\text { company and enable relevant entrepreneurs to start businesses outside the company. Therefore, in order to } \\
\text { achieve this, it is necessary to improve the rates of business success and participation through contact with } \\
\text { relevant companies and policy preferences. }\end{array}$ \\
\hline
\end{tabular}

또한 <Table 5>에서 보는 바와 같이 매년 500명 이상이 해 외봉사단으로 파견되고 있는 상황에서, 이러한 봉사단들을 활 용한 현지사업이나 한국과 연결된 사업모델을 개발하여 실제 로 창업 및 기업 연계한 투자로 이어질 경우, 한국의 국내외 고용창출과 더불어 지속적인 수원국지원의 효과를 달성할 수 있을 것으로 생각된다.

\subsection{2. 민간 기업 투자와 ODA 자금을 연계한 사업 지원 방안}

<Table 6>을 보면, 기존 ODA를 활용하는 민간 기업 투자 사업과 관련하여, 본 연구의 모델을 활용한 분석 결과, 현지의 비즈니스 모델 및 글로벌 창업/취업 지원과의 연계를 통한 발 전가능성도 있는 것으로 분석된다. ODA를 통해 기업 중심의 사업모델 개발과 창업 및 투자에 대한 지원이 이루어진다면, 
기업의 관점에서도 관련 신규 창업자들이나 중소기업의 해외 사업 참여를 유도할 수 있을 것이다. 특히, 이러한 사업모델의 개발 등을 통해 참여할 참여자들에게도 기업 연계를 통해 사 업의 안정성, 성공가능성 등을 높일 수 있으며, 따라서 이러한 부문으로의 정책적 노력도 필요하다고 생각된다.

\subsection{3. 물 관련 $\mathrm{ODA}$ 사업 연계 발전방향}

<Table 7>에서, 기존에 ODA 활용 식수보급 사업과 관련하 여 ODA 기반의 글로벌 창업/취업 지원 모델을 분석한 결과, 직접적으로 현 상황에서의 비즈니스 모델이나 글로벌 창업과 밀접하지는 않으나, 현지 비즈니스 모델 및 글로벌 창업/취업 지원과의 연계를 통한 발전가능성도 발견할 수 있었다.

화장실 및 식수 등 생활용수 부족 지역의 물 공급사업의 경 우에는, 기본적 보건위생의 위협을 받는 상황에서 ODA 지원 이 절대적 필요한 최우선 사업으로 평가될 수 있다. 그러나 이 를 수행하는 데에는 현지의 사정(적정 기술, 인프라, 인력 등) 과 공여국의 공급여력, 지속적 지원 등을 감안할 때, 다양한 한계점을 내포하고 많은 어려움이 따른다. 이러한 난관에도 불 구하고 ODA를 활용해 개선가능성이 있는 경우, 이를 어떻게 접근하느냐가 매우 중요하다. 특히 이러한 자금 지원이 지속되 지 않은 상황에서 현지에서 지속적인 수자원 활용의 기반을 조성하는 것이 필요하므로, 이를 위한 방안 중 하나가 CSV 기반의 민간 $\mathrm{BOP}$ 사업모델 개발, 민간 공급망 형성, 투자를 통한 시장창출 등이다. 즉, 다양한 협업과 시장경제, 새로운 비즈니스 모델(BM)의 개발 등을 통해 지속적인 시너지를 창출 하는 것이 필요하다고 판단된다. 예를 들어, 현지화된 최신 시 스템을 통해 지속적 물의 수요과 공급이 이루어지기 위해서는
$\mathrm{ODA}$ 사업을 활용하여 구축된 참여 민간 기업이나 관련된 사 람들의 역량과 노하우를 기반으로 한 새로운 $\mathrm{BM}$ 과 지속적 투 자가 이루어질 수 있는 구조가 요구된다.

그리고 $\mathrm{ODA}$ 사업은 이러한 $\mathrm{BM}$ 개발의 마중물 역할로 활 용하는 것도 가능해 보인다. 무엇보다도 물의 공급이 부족한 미개발 지역에 대한 물 공급 사업의 성공을 위해서 1개년도 의 사업이 아닌 중장기적인 시각이 필요하다. 특히, 기존 ODA 사업 자금뿐만 아니라 해외 창업 지원자금, 중소기업(인력양 성) 지원 등 다양한 사업자금이 잘 연계하여 활용한다면, 통합 지원 플랫폼으로서 보다 긍정적 시너지를 창출하고 공여국과 수원국 모두에게 이익을 주면서 지속적으로 성과를 창출할 수 있으리라 판단된다.

\subsection{4. 의료보건 관련 $\mathrm{ODA}$ 사업의 연계 발전방향 분석}

의료보건 사업도 물 사업과 유사하게 현지에서의 비즈니스 모델 및 글로벌 창업/취업 지원과의 연계를 통해 그 발전가능 성이 존재한다고 판단된다<Table 8>. 물과 더불어 보건 의료 분야는 개도국의 기본적 발전을 위한 생활수준의 확보와 노동 력의 기본적 공급역량의 유지를 통한 소득창출, 그리고 그러한 시장형성을 위해서 매우 중요한 기본적인 분야이다. 따라서 이 와 같은 보건의료 분야의 지속가능한 공급을 위해서 현지의 시 장과 연계되어 있는 사업모델구축과 비즈니스 투자가 매칭되는 것이 필요하다. 즉, 관련된 기업의 CSR 활동과 연계한 NGO 기반의 투자 사업의 연계, 이를 통한 보건의료 분야의 해외진 출과 일자리창출의 유도, 기존 비즈니스 가치사슬의 재구성을 통한 새로운 부가가치의 창출, 국내외의 관련 민간 기업과의 연계 등을 통해 다양한 방법이 가능할 것으로 판단된다.

Table 7: Analysis of KOICA's Drinking Water Supply Project Using Research Model

\begin{tabular}{|c|c|}
\hline Items & Summary of Content \\
\hline Business overview & $\begin{array}{l}\text { It aims to improve the health of the village by developing wells, providing stable drinking water to the villagers, } \\
\text { supporting toilets and providing health education, and establishing a drinking water supply system. } \\
\text { KOICA safely provided safe drinking water to the four provinces, } 12 \text { villages and } 97 \text { villages in northwestern } \\
\text { Senegal through the first drinking water development project from } 2011 \text { to } 2014 \text { (approximately } \$ 5.5 \text { million). } \\
\text { These villages are vulnerable the impact of drinking water. }\end{array}$ \\
\hline $\begin{array}{l}\text { [1] Supporting } \\
\text { recipient } \\
\text { country }\end{array}$ & $\begin{array}{l}\text { KOICA has established facilities such as sanitation facilities, water towers, pipelines, chlorine disinfection } \\
\text { facilities and water supply facilities, family toilets and public toilets in nine villages in central Senegal, Patik, } \\
\text { Khaolak and Thies to establish drinking water supplies and sanitation facilities. } \\
\text { Because of this, the aid projects for recipient countries have been very successful. However, there are } \\
\text { limitations on sustainability, the spread of performance to neighbors, and the sustainable win-win effect with } \\
\text { donors. }\end{array}$ \\
\hline $\begin{array}{l}\text { [2] Development of } \\
\text { CSV business } \\
\text { model }\end{array}$ & $\begin{array}{l}\text { The development of BM based on CSV is not clearly seen in the current project. } \\
\text { Possibility: There is a possibility that private operators participating in the ODA project will induce voluntary } \\
\text { willingness to pay in the local market, and gradually develop purchasing demand, thereby becoming a business } \\
\text { model that secures economic feasibility in the medium and long term. } \\
\text { New BM development: After all, it is key to develop a structure that is sustainable for these ODA projects and } \\
\text { that can be mutually beneficial for donors, recipient countries and other third party private companies. }\end{array}$ \\
\hline $\begin{array}{l}\text { [3] Global start-ups } \\
\text { /employment } \\
\text { Support }\end{array}$ & $\begin{array}{l}\text { Possibilities: There is plenty of potential if the project's structure is improved and altered so that these projects } \\
\text { can actually be linked to start-up or employment. } \\
\text { Development of new structure through linkage with other projects: there is a new possibility if it is linked not } \\
\text { only to basic ODA funds but also to related start-up support funds, to overseas expansion support funds, and } \\
\text { to SME CSR support. }\end{array}$ \\
\hline
\end{tabular}


Table 8: Analysis of KOICA's Medical Health Project Using Research Model

\begin{tabular}{|c|c|}
\hline Items & Summary of Content \\
\hline Business overview & $\begin{array}{l}\text { It focuses on providing financial and technical support to comply with international health regulations, with a } \\
\text { focus on vaccinations, medical staff development, and laboratory strengthening in Cambodia, and it have } \\
\text { developed a nationwide testing system that can respond to the threat of antibiotic resistance through the } \\
\text { detection and identification of pathogens causing infectious diseases. } \\
\text { The ENT department in Cambodia, Ang Duong Hospital, lacks the provision of medical services in line with } \\
\text { demand, and the facilities are also very poor. The Ang Duong Hospital ENT Center, completed through the } \\
\text { same project, is a five-story building with state-of-the-art medical equipment. } \\
\text { KOICA started the Bolivia Health System Improvement and Medical Manpower Enhancement Project since 2010, } \\
\text { and opened the Oruro 3rd General Hospital, which began construction in September } 2014 \text { and finished in } \\
\text { March 2017. Afterwards, KOICA dispatched KOICA experts to strengthen the capacity of medical personnel and } \\
\text { provided advice on efficient hospital operation. }\end{array}$ \\
\hline $\begin{array}{l}\text { [1] Supporting } \\
\text { recipient count }\end{array}$ & $\begin{array}{l}\text { es. } \\
\text { ds to be } \\
\text { fits. }\end{array}$ \\
\hline $\begin{array}{l}\text { [2] Development of } \\
\text { CSV business } \\
\text { model }\end{array}$ & $\begin{array}{l}\text { In the current business, direct development is rather weak. } \\
\text { Development of various BMs: In order to develop a private-centered linked business model for the continuous } \\
\text { dissemination of local people, various attempts should be made, such as the discovery of actors with } \\
\text { entrepreneurship and the development of CSV-based business models using ODA funds. } \\
\text { Efforts to connect with various subjects: In particular, such a business entity may be NGOs or social } \\
\text { enterprises with relevant business experience, given the nature of the health care sector. }\end{array}$ \\
\hline $\begin{array}{l}\text { [3] Global start-up } \\
\text { lemployment } \\
\text { Support }\end{array}$ & $\begin{array}{l}\text { There is only potential for current business. } \\
\text { Efforts to Connect with Various Businesses and Subjects: Based on the developed business model and } \\
\text { entrepreneurship, it is necessary to carry out investment, incubating and accelerating business locally so that } \\
\text { they can develop the actual business and to create related jobs. }\end{array}$ \\
\hline
\end{tabular}

Table 9: Analysis KOICA Projects Related to Agriculture Using Research Model

\begin{tabular}{|c|c|}
\hline Items & Summary of Content \\
\hline Business overview & $\begin{array}{l}\text { Establishes a "processing of agri-food and marketing national strategy" for rice and corn, Uganda's main grain: } \\
\text { Strengthening capacity for farmers and processors, supporting the establishment and operation of rice and corn } \\
\text { pilot processing centers, and supporting management equipment after farming. } \\
\text { With the aim of increasing the rice self-sufficiency rate in the Satin-Louis region in the north of Senegal, the } \\
\text { Senegal Agricultural Research Service is working on strengthening rice breeding and cultivation technology } \\
\text { research capacity and the government's dissemination system of excellent seeds. } \\
\text { Myanmar's first farmers leader training center opened at the Agricultural and Irrigation Agricultural Research } \\
\text { Institute in Naypyidaw, Myanmar. The Myanmar Rural Community Development Project, which has been } \\
\text { investing \$2 million since 2015, supports an average of } 30 \text { million won per village per year to nurture rural } \\
\text { village leaders and develop residents' capabilities and increase incomes in } 110 \text { pilot villages in } 10 \text { provinces. }\end{array}$ \\
\hline $\begin{array}{l}\text { [1] Supporting } \\
\text { recipient } \\
\text { country }\end{array}$ & $\begin{array}{l}\text { food production, following water and health care, } \\
\text { ndustrialization in recipient countries. } \\
\text { tor and it is very important to promote the support } \\
\text { f a market based on supply and demand. }\end{array}$ \\
\hline $\begin{array}{l}\text { [2] Development of } \\
\text { CSV business } \\
\text { model }\end{array}$ & $\begin{array}{l}\text { In the current business, there is a possibility of linking with a market-based business model, such as processing } \\
\text { agricultural products for rice and corn and linking national marketing strategies. } \\
\text { Creating shared value through diversification of improvement agents: Based on the level of local market and } \\
\text { local supply capacity, the relevant business model should be developed centering on relevant private companies } \\
\text { or business entities. In the end, it is necessary to improve the level of the entire supply base so that a } \\
\text { business model can be developed that can create shared value. }\end{array}$ \\
\hline $\begin{array}{l}\text { [3] Global start-ups } \\
\text { lemployment } \\
\text { Support }\end{array}$ & $\begin{array}{l}\text { Development and support of various linked investments: If the developed business model and the business } \\
\text { owners who developed these models support various connected investments to carry out the actual business, it } \\
\text { will be possible to achieve start-up and job creation effects. }\end{array}$ \\
\hline
\end{tabular}

\subsection{5. 쌀 및 농업 관련 $\mathrm{ODA}$ 사업의 연계 발전방향 분석}

<Table 9>와 같이 기존에 ODA를 활용하는 농업사업과 관 련하여 ODA를 활용한 글로벌 창업/취업 지원 모델로 분석한 결과, 현지 비즈니스 모델 및 글로벌 창업/취업지원과의 연계
와 그를 통한 발전가능성은 존재한다고 판단된다. 농업은 지속 가능개발목표(SDGs) 중 '식량안보와 영양 개선, 빈곤과 기아 의 극복’에 직접적으로 기여하며, 해양 및 산림의 지속가능한 보존과 개발, 일자리 창출, 지속가능한 생산과 소비와도 연관 된다. 따라서 농업 분야의 개발원조 확대는 SDGs 달성에 직 
접적으로 기여할 수 있으므로, 동 분야는 민간 중심의 ODA 활용 글로벌 창업(또는 취업) 지원 모델을 실제로 적용할 수 있는 모범 분야라 판단된다.

특히, 현재 수행되고 있는 ODA사업과 관련해 사업을 진행 하고 있는 기업체나 관련 종사자 중 민간 중심으로 비즈니스 모델 개발과 투자를 진행할 수 있도록 ODA 자금을 연계 활용 및 지원할 경우, 단기적으로는 물론 중장기적으로는 가시적인 사업성과가 가능한 분야로 판단된다(KOICA, 2017b).

\section{2. $\mathrm{ODA}$ 활용 모델 관련 인터뷰}

\subsection{1. 경제부처 고위공무원과의 인터뷰}

인터뷰 결과, 고위공무원들은 ODA를 활용한 글로벌 창업/ 취업 지원 모델의 실행을 위해서는 산하기관의 연계 프로젝트 메니저(PM) 제도가 필요하며, 그러한 프로젝트 매니저의 역할 이 중요하다고 언급했다. 특히, 비즈니스 모델의 개발 및 창업과 연계해 민간주체가 수행하는 내용을 관리하고 감독을 지원하는 역할은 매우 중요하다고 판단되었다. 예를 들어, 한 부처의 국장 (한국인)은 자신이 ODA 자금으로 200억 원을 지원받아 베트남 의 현지에 (농업기술 개발을 위한) 테크노파크를 성공적으로 설 립하고, 원전 수주 노력의 경험도 보유하고 있으며, 베트남 농수 산 분야와 관련하여 성공적 아이디어를 제공하기도 했다고 밝혔 는데, 그 분의 역할이 바로 $\mathrm{PM}$ 의 역할이라는 것이다.

한편, 베트남 현지에서 사용되는 식재료는 농약검사, 품질보 증이 어려운 상황이며, 따라서 “검수 기능”이 제공된다면, 한국 의 CJ 등 한국 식품회사들의 수입 소싱도 가능하다고 보았다. 그리고 이를 통해 관련된 비즈니스 모델의 개발 및 창업지원 을 통한 일자리 창출도 가능하다는 것이다. 또한, 농기계 분야 에 있어서도 베트남 현지에서 제조 및 공급을 위한 기술자와 전문 인력이 긴요한 상황이라는 것이다. 따라서 그러한 사안에 대해 한국의 생산기술연구원에서 프로젝트를 추진하고 있다고 설명했다.

전반적으로 현지의 시장 수요나 사업에 기반을 둔 한국인에 대한 고용수요와 한국의 고용 공급역량, 그리고 공급 의사 사 이에서 존재하는 간격(Gap)을 어떻게 본 모델을 활용해 정부가 매칭할 수 있는지가 사업 성공을 위해 매우 중요하다고 판단된 다. 즉, 현지의 시장수요에 기반을 둔 $\mathrm{BM}$ 의 개발과 한국의 노 동공급의 역량확보, 그리고 의지를 가진 주체들의 확보를 동시 에 고려하면서 모델의 수행전략을 고민해 보아야 할 것이다.

\subsection{2. 신흥국 진출업계 관계자 인터뷰}

인터뷰의 대상자는 인도를 기반으로 한 신흥국 진출 비즈니 스를 위주로 하는 컨설팅 전문업체의 대표로서, 다양한 비즈니 스 컨설팅을 수행한 사람이다. 인터뷰를 하면서 이론보다는 실 무적인 측면에서 ODA 활용를 활용한 고용창출 모델에 대한 타당성과 발전방향, 문제점 등에 대해 질문하였다.

인도에 대한 ODA 자금을 활용한 창업/취업 지원 또는 기업 의 현지투자와 관련하여, 한국은 인도에 대한 ODA 자금 지원 이 최근에는 가능하게 되었음을 밝혔다. 현재까지는 없었지만 오랜기간 ODA 자금을 활용해 기업의 인도 진출을 지원한 일 본의 경우, 한국과 비교할 때 매우 큰 성과를 보이고 있다. 인 도에 진출한 일본 기업의 숫자가 10 년 전에는 500 여개사에서 현재는 2,000 여개사로 4 배 가까이 증가된 상황이며, 이와 같
은 일본기업의 인도 내 진출 확대는 일본정부의 ODA 자금이 기여한 공로가 큰 것으로 추정된다. 대조적으로, ODA 자금을 활용하기 어려웠던 한국기업은 인도 진출한 기업의 수가 10년 전이나 지금이나 큰 차이가 없는 상황이다. 한편 최근에는 인 도도 한국이 ODA 사업 자금을 투자하기로 결정함으로써, 인 도 내 사업 모델의 개발과 현지 투자를 연계하는 ODA 자금의 이용 가능성은 높은 것으로 판단되었다.

창업과 관련해서도 인도 사업 환경의 특징상 제조업의 창업 은 다소 어렵지만, 바이오나 IT 분야 서비스업에 대해서는 창 업기회가 많을 것으로 판단되었다. 이와 같이 ODA 자금을 활 용한 창업이나 고용창출이 발생하기 위해서는 이를 매칭할 수 있는 비즈니스 모델(BM)의 개발을 위한 투자가 필요한 상황이 다. 특히, 비즈니스 모델 개발에 대해서 한국 정부는 ODA 자 금이 매우 제한적이고, 실물위주의 ODA 자금만 사용되는 현 상황에서, 의미 있는 사업화가 고용창출로 연결되는 것은 다소 시간이 필요할 것으로 밝혔다. 즉, 단기간의 과시성 사업 위주 의 ODA 사업이 중심이 되는 현실에서, 민간사업과의 연결을 통한 비즈니스 모델 개발과 이러한 사업을 실행한 사업주체의 투자, 그리고 이를 고용창출로 연결시키는 것은 다소 어렵다는 것이다. 따라서 무조건적으로 단기간 내에 가시적 성과만을 추 구하기 보다는 중장기적이며 거시적 관점에서 이러한 전략 모 델을 염두에 두고 노력해야 할 것이다.

\subsection{CSV 비즈니스 모델에 기반한 한국적 ODA 수행 전략}

무상원조이든 유상원조이든 이제는 한국의 실정에 맞는 새 로운 ODA 수행전략을 찾아야 할 때이다. Kwon, Kim, Park, Hwang, and Hong (2006)에 따르면 한국적 ODA는 기존의 공 여국과 차별화시킬 수 있는 한국만의 고유한 특징과 비교우위 를 지닌 원조라고 명명하였고, Jeon, Lee, Lee, and Son (2007)은 국제적 원조규범을 기반으로 하여, 선진국 원조와 차 별되는, 예를 들어 비교우위 분야에 집중하여 한국의 국가브랜 드 가치와 국력을 높이는 사업이라고 보았다. 또한, Jung(2010)은 그동안 성공적인 개발을 이끌었던 지식, 제도, 기술 등을 다른 개도국과 공유하여 국제적 목표 달성에 기여 하는 사업이면서 한국에 비교우위가 있는 분야의 원조라고 보 았다.

특히, Jung et al.(2014)은 이러한 한국적 ODA를 실제 수행 하기 위하여, Porter and Kramer(2011)의 CSV 방법을 업그레 이드한 다음과 같은 방법을 강조하였다. 즉, (1) 해당 공여국에 서 다른 국가 대비 강점을 가지고 있는 핵심역량(core competence)을 파악하고, (2) 이러한 공여국의 핵심역량과 수 요자의 니즈를 근거로 타겟시장(또는 제품)을 발견하고, (3) $\mathrm{ODA}$ 의 가치사슬을 재발견 및 조정한 뒤, (4) 점차 해당 ODA 수행의 인프라 측면인 혁신 클러스터를 개발하고 국제적으로 연계시킨다는 것이다. 이러한 $\mathrm{ODA}$ 수행에 대한 개념은 $<$ Figure $4>$ 와 같다.

본 연구에서는 일부 사례를 통해 그 가능성을 타진해 보았 으나, 실제 위와 같은 수행전략을 참고한다면 수원국의 효과도 증대시키면서 창업과 일자리를 창출하는 지속가능한 비즈니스 모델(BM)의 개발도 그 가능성을 보다 증가시킬 수 있으리라 판단된다. 


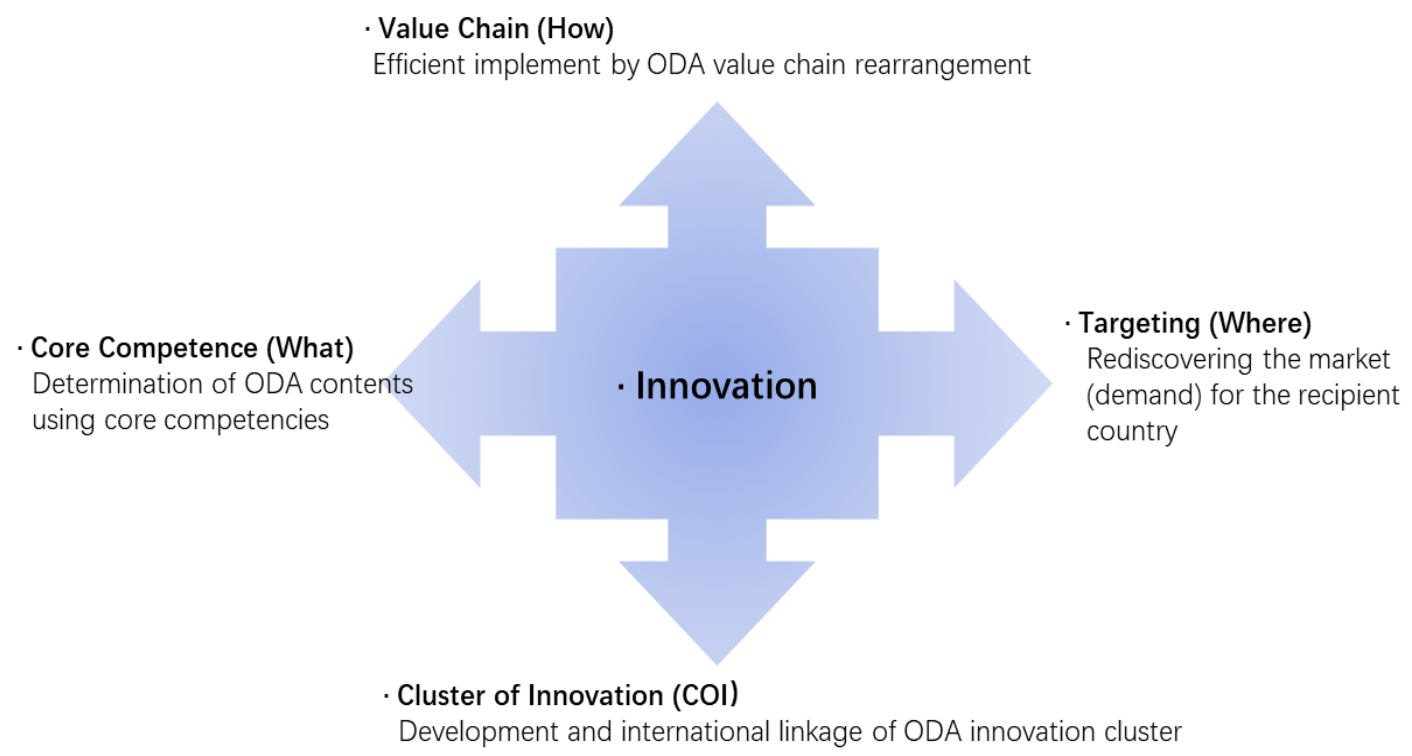

Source: Jung, Lee, and Yun (2014).

Figure 4: Korean ODA Strategy Based on CSV Business Model

\section{4. 결론}

기본적으로 $\mathrm{KOICA}$ 는 무상원조를 제공하는 대표적 기관이 다. 그런데, KOICA가 수원국의 국익외에 공여국의 어떤 목적 을 가지고 ODA 사업을 수행하는 것이 타당할 것인가? 본 연 구는 이러한 이슈에 대한 새로운 시각에서 출발하였다. 과거 무상원조를 하는 EU 등 많은 국가들이 주로 공여국의 이익을 위해 $\mathrm{ODA}$ 를 수행하는 일본 등에 대해 비판해온 것이 사실이 다(Kawai \& Takagi, 2004). 그러나 최근 그 추세가 바뀌고 있 다. 중국이 일대일로(一帶一路, One belt, One road)를 내세우 면서 ODA를 통해 수원국과 많은 경제협력을 통해 윈윈전략을 수행하고 있으며, 앞서 밝힌 일본 역시 마찬가지이다. 유럽 등 다른 선진국의 인식 또한 변화하고 있다. 따라서 본 연구에는 한국 KOICA의 ODA 사업 또한 이러한 세계적 추세에 발맞추 어는 것은 중요하며, 매우 타당하고 필요한 상황이 아닌가 판 단된다.

앞에서 분석한 사례를 종합적으로 분석해 볼 때, 현재 진행 중인 고용노동부의 ODA 사업뿐만 아니라 향후 각종 KOICA $\mathrm{ODA}$ 사업과 연계해 고용창출과 연결되는 사업모델 개발과 글 로벌 창업 및 취업을 통해 고용창출을 지원하는 사업의 발굴 과 추진은 충분히 의미 있는 시도라고 판단된다. 보다 구체적 으로 <Table 10>에서 보는 바와 같이, 본 연구에서 분석한 5 가지 기존 사업 중 민간 기업 투자와 ODA 자금을 연계한 사 업에서의 고용창출, 코이카 해외봉사단 파견 사업의 고용노동 부 사업과의 연계 등은 그 실현가능성이 높아 후속연구를 통 해 구체적 실행방안과 사업 타당성을 모색할 수 있다고 판단 된다. 이와 같이 민간사업이 중심이 되면서 수원국에 대한 지 속가능한 지원이 CSV 비즈니스 모델 개발 사업과 더불어, 수 원국 지원과 동시에 공여국의 고용창출을 동시에 달성하는 방 향으로 ODA사업을 추진하는 것도 하나의 새로운 성공모델이
될 수 있을 것으로 기대된다.

본 연구 결과는 실행을 위한 방향성 도출과 밀접한 연구이 다. 본 연구결과를 바탕으로 구체적 실행을 위해서 본 연구에 서 제시한 몇 개의 분야에 대해 후속사업을 통한 필드연구도 필요하리라 생각된다. 또한, 현장기반 연구에서는 관련 분야에 서 종사하는 NGO와 민간기업을 포함하여 기존에 수행되는 사 업의 관계자들에 대한 다양한 의견수렴과정을 통해, 실행 가능 한 정책대안의 도출이 필요하다.

최근 UN의 SDGs가 중요한 이슈이며, 이러한 지속가능한 발전이 인류의 도전이 되고 있다. 단순히 무조건적인 무상원조 에는 한계가 있으며, 그러한 방식으로 SDGs를 달성하는 방식 은 이제 변화해야 할 때이며, 따라서 인식의 전환이 필요하다. 이러한 사고를 뒷받침하는 이론적 배경의 핵심이 포터의 CSV 개념이며(Jung \& Lee, 2012), KOICA의 실제 ODA 사례를 통 해 이를 고찰 및 검증하려는 시도가 본 연구의 목적이다. 일반 적으로 $\mathrm{ODA}$ 는 그 수행의 타당성, 현실 가능성, 수원국 및 공 여국의 상황 및 의도 등 다양한 측면이 적합해야 하며, 따라서 수행을 하는 기관이나 정부의 ODA 수행이 그러한 정당성을 확보해야 한다(Jung \& Oh, 2011). KOICA의 ODA 사업 역시 예외는 아니다. 본 연구에서 제시한 모델이 새로운 조그만 기 초가 되어, 무상원조 ODA를 새롭게 인식하는 기반이 될 수 있으리라 생각된다.

본 연구는 주로 사례분석을 위주로 진행하였으며, 여러 원조 의 형태 중에서 무상원조를 주로 하는 KOICA의 ODA 사례를 다루었다는 점 등 일반화하기에는 어려운 몇 가지 한계점은 내 포하고 있으나, SDGs, CSV, 공유경제, 사회적 책임 등 새로운 이슈가 등장하고 무상원조 ODA도 변화해야 하는 현 상황에서, 중요한 이슈를 제기하고 모델 제시를 했다는 측면에서 그 의미 를 찾을 수 있다. 또한, 이를 기반으로 정책관련자 및 향후 후 속 연구에도 의미 있는 시사점을 제시하리라 판단된다. 
Table 10: Comprehensive Feasibility Evaluation of Policy Cases Using Global Start-ups/Employment Support Model Based on ODA

\begin{tabular}{|c|c|c|c|}
\hline Classification & Business name & Main contents (Title of press release) & $\begin{array}{l}\text { Feasibility } \\
\text { (level) }\end{array}$ \\
\hline \multirow{5}{*}{$\begin{array}{l}\text { KOICA } \\
\text { business } \\
\text { linking } \\
\text { field policy }\end{array}$} & $\begin{array}{l}\text { Linkage with the Ministry of } \\
\text { Employment and Labor of the KOICA } \\
\text { Overseas Volunteer Corps }\end{array}$ & $\begin{array}{l}\text { The outline and recruitment guide of Overseas Volunteer } \\
\text { Corps Project } \\
\text { Opening ceremony for KOICA Volunteer Corps } \\
\text { KOICA East Timor Office signed an agreement with the UNDP } \\
\text { to send international development volunteers } \\
\text { KOICA holds firstly Field Project Donation Ceremony for Ivory } \\
\text { Coast Health Education Volunteers } \\
\text { Volunteer service for Cambodian students who study Korean. } \\
\text { KOICA-Gyeongsangbuk-do holds Inauguration Ceremony for } \\
\text { the First Saemaul Leaders }\end{array}$ & High \\
\hline & $\begin{array}{l}\text { Project linking private enterprise } \\
\text { investment with ODA funds }\end{array}$ & $\begin{array}{l}\text { KOICA and CJ succeed on rural development in Vietnam. } \\
\text { 'CJ pepper powder wins 'Vietnam farmers' life' } \\
\text { KOICA-Kia Motors turns green light on Ethiopian Automotive } \\
\text { Maintenance } \\
\text { KOICA, together with Lotte, pursues win-win development in } \\
\text { the distribution industry in Vietnam }\end{array}$ & High \\
\hline & Water related ODA business & $\begin{array}{l}\text { KOICA distributes clean drinking water to } 100,000 \text { rural poor } \\
\text { rural areas in Senegal. }\end{array}$ & Middle \\
\hline & Medical Health related ODA Project & $\begin{array}{l}\text { KOICA joins forces with international community to strengthen } \\
\text { Cambodia's ability to prevent epidemics. } \\
\text { KOICA established General Hospital in Oruro City, Bolivia. } \\
\text { KOICA signed the minutes of Cambodia Andu Enh Hospital's } \\
\text { Otolaryngology Capacity Building Project. }\end{array}$ & Middle \\
\hline & ODA business related to agriculture & $\begin{array}{l}\text { Uganda, let's try rice processing miracle like Korea. } \\
\text { KOICA becomes a platform for rural development in } \\
\text { developing countries. } \\
\text { KOICA contributes to Senegal rice self-sufficiency by utilizing } \\
\text { recipient system. } \\
\text { KOICA establishes Myanmar Rural Development Training } \\
\text { Institute to nurture rural village leaders. }\end{array}$ & Middle \\
\hline
\end{tabular}

Note: The feasibility assessment is based on a combination of external interviews and internal researchers' own assessments.

\section{References}

Baxter, L.(2016). A Grounded Theory Study of the Establishment of Public-Private Alliances in Official Development Assistance Programmes. Journal of International Development, 28(4), p569-587.

Benmamoun, M., \& Lehmert, K.(2013). Financing Growth: Comparing the Effects of FDI, ODA, and International Remittances. Journal of Economic Development. 28(2), 43-65.

Eregha, P. B., \& Oziegbe, T. R.(2016). Official Development Assistance, Volatility and Per Capita Rear GDP Growth in Sub-Saharan African Countries: A Comparative Regional Analysis. The Journal of Developing Areas, 50(4), 363-382.

Gai, J., \& Jung, J. S.(2012). Korea's Strategy Concerning the Allocation of Official Development Assistance (ODA): Based on an Empirical Test of Asian Countries. Research on Journal of CEO and Management Studies, 15(2), 81-102.
Ghasemi, S., Nazemi, M., \& Hajirahimian, T.(2014). From Corporate Social Responsibility (CSR) to Creating Shared Value (CSV): Case Study of Mobarakeh Steel Company. Global Business \& Management Research, 6(1), 15-23.

Graves, C.(2015). Why Modernise Official Development Assistance? OECD Observer, 303, 18-18.

Jeon S. H., Lee K. K., Lee J. H., \& Son S. A.(2007). A Study on the Development of Korean Development Cooperation Program.

Jin, C. H.(2018). The Effects of Creating Shared Value (CSV) on the Consumer Self-brand Connection: Perspective of Sustainable Development. Corporate Social Responsibility \& Environment Management, 25(6), 1246-1257.

Jung, J. H.(2016). A Study on Improvement of Self-evaluation of Employment Impact on ODA.

Jung, J. S., \& Lee, M. J.(2012). Scientific Technology ODA Strategy Using Appropriate Technology: Based on Creating Shared Value. Korean 
Management Consulting Review, 12(4), 421-443.

Jung J. S., Lee, M. J., \& Yoon, Y. H.(2014). Korea's ODA Strategy Based on Creative Shared Value. International Business Review, 18(4), 75-99.

Jung, J. S., \& Oh, J. S.(2011). An Introduction of Korean ODA Framework Rooted in Porter's Diamond Model. Korea Research Academy of Distribution Information Review, 14(6), 123-141.

Jung, M. S.(2012). A Study on the Strategies for Advancing Emerging Countries. (Samsung Economic Research Institute Research Report).

Jung M. S., \& Khoe, K. I.(2013). Analyses on Mutual Win-win and Packaged Emerging Market Entry Strategy of Governance. Korean Management Consulting Review, 13(3), 239-258.

Jung , W. J.(2010). Korean Development Cooperation Model. KOICA.

Kawai, M., \& Takagi, S.(2004). Japan's Official Development Assistance: Recent Issues and Future Directions. Journal of International Development, 16(2), 255-280.

KEP(2017). 2016 Global Entrepreneurship Trend Report. Korea Youth Entrepreneurship Foundation.

Kim, B. H.(2002). A Comparative Study on the Motivations and Types of ODA in Developed Countries (Master's Thesis). Yonsei University, Seoul, Korea.

Kim, S. J., \& Kim, S. C.(2019). Review of Corporate Social Responsibility Effects Studies. International Journal of Industrial Distribution \& Business, 10(7), 17-27.

Kim, T. H.(2016). ODA Effects in Middle Asian Countries and Strategic Revitalization of Economic Cooperation. Journal of International Trade and Industry Studies, 21(3), 8-1103.

KOICA(2017, September 29). KOICA Becomes Platform for Rural Development in Developing Countries.

KOICA(2017, June 14). KOICA Becomes Platform for Rural Development in Developing Countries.

Korea Labor Institute(2016). Improving Self-evaluation of Employment Impact on ODA. Ministry of Employment and Labor (MOEL).

KOTRA(2011). Global ODA, Find Successful DNA, KOTRA In-depth Report 11-028.

Kwon, Y., Kim, H. S, Park, B. Y., Hwang, J. S., \& Hong, S. Y.(2006). Overall strategy for Korean ODA Reform. Korea Institute for International Economic Policy.

Lee, K. K.(2017). Status and Challenges of Employment Labor ODA for Sustainable Development. International Trade Law, 2017-2, 1-10.

Lee, S. W.(2016). ODA Policy for Promoting SMEs in Developing Countries in SDGs Era: By Supporting
Policy Instruments (KIET.WERI Research Report 2016-785).

Lee, Y. J.(2013). A Plan for Activating Entrepreneurship in the Era of Creative Economy. Science and Technology Policy, 23(2), 10-21.

Lee, Y. J.(2014). Global Entrepreneurship Index and Its Implications on Korean Start-up Environment (STEPI Policy Research Report 2014-08).

Leslie, H. M., Banks, G., Prinsen, G., Scheyvens, R., \& Stewart-Withers, R.(2018). Complexities of Development Management in the 2020s: Aligning Values, Skills and Competencies in Development Studies. Asia Pacific Viewpoint, 59(2), 235-245.

Min, K. D., Huh, M. Y., \& Han J. H.(2018). A Success Factor for Technology Commercialization for Start-ups by the Weighted-BMO Model. International Journal of Industrial Distribution \& Business, 9(11), 39-54.

Ministry of Economy and Finance(2014). Win-Win Economic Cooperation Roadmap. Dong-A University Institute for International Trade.

Park, B. Y., Kim, J. Y., \& Lee, H. S.(2014). ODA Effects in Middle Asian Countries and Strategic Revitalization of Economic Cooperation. Journal of International Trade and Industry Studies, 19(2), 85-111.

Park, H. S.(2017). Environmental Assessment of Korean Entrepreneurship Through International Comparison of Entrepreneurship Index. KER/ Brief, 17-02.

Park, J. B.(2016). Toward the Green Comfort Zone: Synergy in Environmental Official Development Assistance. Global Environmental Politics. 16(4), 1-11.

Porter, M. E., \& Kramer, M. R.(2011). The Big Idea: Creating Shared Value. Harvard Business Review, 89, 2-17.

Prahalad, C. K.(2004). The Fortune at the Bottom of the Pyramid: Eradicating Poverty Through Profits. Philadelphia, PA: Wharton Business Publishing.

Refaei, R., \& Sameti, M.(2015). Official Development Assistance and Economic Growth in Iran. International Journal of Management, Accounting \& Economics, 2(2), 125-135.

Riddell, R. C.(2007). Foreign Aid: Diplomacy, Development, Domestic Politics. Chicago, IL: Chicago University Press.

Riddell, R. C.(2014). Does Foreign Aid Really Work? Oxford, United Kingdom: Oxford University Press.

Win, T., \& Cho, Y. C.(2018). Exploring Effectiveness of Official Development Assistance: Comparison Analysis of Developing Countries. Journal of Marketing Thought, 5(3), 22-32. 